\title{
A Three-Dimensional Jigsaw Made of Pliable Bits: Analysing Adolescent Identity as an Intertextual Construct in Aidan Chambers' Postcards from No Man's Land (1999)
}

\section{Leander Duthoy ${ }^{1}$ (1)}

Published online: 11 July 2020

(C) The Author(s) 2020, corrected publication 2020

\begin{abstract}
YA fiction is well known for a prevalence of narratives that explore identity and identity change. Critics have constructed multiple theoretical frameworks that help put into words the workings of adolescent identity in these novels. This article adds to that discussion by analysing Jacob, the main character of Aidan Chambers' Postcards from No Man's Land, (The Bodley Head, London, 1999), through the framework of Julia Kristeva's intertextual theory, where any socio-cultural element can be an intertext, from a specific song to a political ideology. By returning to Kristeva's original broad interpretation of textuality, I consider Jacob's identity itself a text, shaped by the intertexts in his socio-cultural environment. My analysis then focuses on how Jacob's process of identity development is empowered through the various intertexts with which he is presented over the course of Postcards' narrative.
\end{abstract}

Keywords Aidan chambers · Intertextuality $\cdot$ Identity $\cdot$ YA fiction · Postcards from no man's land

\section{Introduction}

Young adult literature does not shy away from controversial topics. When Aidan Chambers' Postcards from No Man's Land (1999) was awarded the Carnegie medal in 1999, critics questioned whether the book was even suitable for adolescent readers, as it deals with "euthanasia, adultery, sexual discovery, and homosexuality" (Greenway, 2006, p. 99). In general, YA fiction often faces criticism from those who

\footnotetext{
Leander Duthoy is a PhD student at the University of Antwerp, working on the ERC funded project: Constructing Age For Young Readers (CAFYR). He has a BA in education (English/history), and an MA in English Literature and Linguistics.
}

Leander Duthoy

Leander.Duthoy@uantwerpen.be

1 Faculty of Arts: Department of Literature, University of Antwerp, Antwerp, Belgium 
wish to protect the young from these types of topics, which has led to multiple YA books being banned (Mertz, 1978, p. 101; also Smith, 2019). This tension is both contradicted and reinforced by YA fiction's soaring popularity.

In this article I hope to add to this ongoing critical debate by presenting an applied theoretical discussion of a single text using a theoretical framework of intertextual theory to analyse the identity of adolescent protagonist Jacob in Chambers' Postcards from No Man's Land. By returning to Julia Kristeva's original interpretation of textuality - which was broader than the networking of cultural artefacts to which it is now often reduced-Jacob's identity itself becomes an intertextual construct, built from the intertexts provided by the socio-cultural environment. In my analysis, I focus on how Jacob's encounters with the novel's intertexts, including its more controversial subjects, are significant for his identity development. In short, this article intends to demonstrate how an intertextual reading can support and add to theoretical frameworks that help understand the workings of adolescent identity in YA fiction. In support of my later analysis, a theoretical framework of intertextuality will first be constructed. This will aim to answer two questions: what is "intertextuality" within the parameters of this article, and why/how can it be linked to the adolescent experience?

\section{Theoretical Framework}

Defining intertextuality is difficult. Though the concept was originally coined by Julia Kristeva in the 1960s, so many different scholars have now (re)interpreted it that some have argued that the entire idea has become "unstable in meaning" (Clayton and Rothstein, 1991, p. 18) or "underdetermined in meaning and overdetermined in figuration" (Allen, 2011, p. 2). Considering this overabundance of interpretations of intertextuality, I do not aspire to establish an all-encompassing definition of what intertextuality is or should be. My main focus will be on Kristeva's paradigm, as she is generally recognized as the first to consolidate various ideas into a coherent intertextual theory, and it is her interpretation of intertextuality which forms the foundation on which my argument is built (Polaski, 2001, p. 33).

A discussion of intertextual theory that seeks to remain faithful to Kristeva's original intent, requires clarification of what the word "text" means within her paradigm. For Kristeva, a text and a written piece of literature are not synonyms. Rather, when Kristeva uses the word text, she harkens back to an older interpretation of the word, derived from the same root as textile: woven fabric. That image of weaving a text together is a core metaphor of intertextual theory. It highlights how, for Kristeva, a text is any cultural element that is woven out of various threads (Allen, 2011, p. 6). Accordingly, the scope of the Kristevan text is considerably broader than only literary works, or as Manfred Pfister writes, "everything-or, at least, every cultural formation-counts as a text within [Kristeva's] general semiotics of culture" (1991, p. 212).

What are then the threads from which Kristevan texts are woven? As Irwin writes, "all texts derive their meaning only through their relations to other texts" (2004, p. 229), thus, the threads that make up a text, are other texts. Kristeva's 
intertextuality envisioned culture itself as a network of interconnected texts of every kind, whose meaning is constructed from and transformed by the other texts in that network (Kristeva, 1986, p. 37). This is why Still and Worton argue that all texts are "shot through with references, quotations and influences of every kind" (1990, p. 1), later adding that we "construct our 'lives' in relation to texts, whether these be Proust or television soap operas" (1990, p. 19). Even concepts as abstract as history and society are texts and part of the intertextual system (Irwin, 2004, p. 229).

Though Kristeva's work lies at the core of my argument, the intertextual theories of Harold Bloom also offer a very interesting lens to take a more in depth look at one of Jacob's most vital intertexts. One can read fragments of Bloom's work and think his interpretations to be similar to Kristeva's. For example, Bloom writes that "there are no texts, but only relationships between texts" (Bloom, 1975 , p. 3). While that might appear to echo Kristevan ideas, there are significant differences. Most notably, Bloom does not adopt a new definition of textuality, when he writes about relationships between texts, he means literary texts (Allen, 2011, p. 137). Nevertheless, as I will indicate later, his perspectives can still be adapted to support a Kristevan reading.

When attention is shifted to the level of the reader-in this context meaning the person interpreting a text-such a broad and virtually limitless network of textuality may initially appear daunting. Thankfully, it is not required-nor is it possible-for the reader to be aware of every textual strand in a given text. Instead, certain texts within the network will have much more significance than others. To clarify this, I will use the term "intertext" as defined by Michael Riffaterre: "one or more texts which the reader must know in order to understand a work of literature in terms of its overall significance" (1990, p. 56). "Must know" is perhaps rather narrow, but it does highlight that certain intertexts affect a text's significance to a larger extent, which I also illustrate later.

The entirety of all texts that are available to an individual or a society is sometimes called the "social text" or "cultural text" (Irwin, 2004, p. 237; Allen, 2011, p. 35). For Kristeva, the social text consists of "those social practices of which 'literature' is only one unvalorized variant" (Kristeva, 1986, p. 87). In other words, the social text also encompasses more abstract and difficult to summarize socio-cultural and historical texts. Allen argues that the social text contains "all the different discourses, ways of speaking and saying, institutionally sanctioned structures and systems which make up what we call culture" (2011, p. 35), while Clayton and Rothstein emphasize "the network of anonymous ideas, commonplaces, folk wisdom, and clichés that make up the background of one's life" (1991, p. 22). A text can only "emerge" through this social text, thus any text is therefore situated within history and society itself (Allen, 2011, p. 36).

Despite its importance, there remains one text I have not explicitly named as such, namely the individual/subject. In Kristevan intertextuality, "the subject is composed of discourses, is a signifying system, a text, understood in a dynamic sense" (Still and Worton 1990, p. 16). Similarly, Clayton and Rothstein write that for Barthes, intertextuality: 
encompasses more than the idea that we all possess conventional knowledge whose sources we cannot recall. It extends toward a notion of the subject as constituted by the texts of its culture, the subject as the already read. (1991, p. 22)

In other words, human identity is also constructed or woven out of the texts found in a unique individual social text created by particular circumstances, and the more general social text of culture, shaped by history and society. If our identity is "constituted by the texts of [our] culture" (Clayton and Rothstein, 1991, p. 22), then comprehending someone's "significance" entails identifying important intertexts (Riffaterre, 1990, p. 56). Thus, the second half of this article highlights some of the vital intertexts necessary to understand the "significance" (i.e. the identity) of Postcards' protagonist Jacob.

However, before any intertextual analysis can start, it first needs a way to navigate the unfathomably complex social text. Polaski points out that "[s]uch a wide-open field for interpretation renders interpretation problematic. It is impossible to consider the relation of a text to all other residents which inhabit intertextual space" (2001, p. 34). Thankfully, Riffaterre offers a relatively straightforward solution, writing that "we must distinguish between the actual knowledge of the form and content of [an] intertext, and a mere awareness that such an intertext exists and can eventually be found somewhere" (1990, p. 56). In agreement with this point, I have selected intertexts with which Jacob explicitly interacts and which directly appear to impact his identity.

Of course, I do not want to suggest that analysing identity is as easy as listing intertexts. Identity is a complex concept and, much like intertextuality, challenging to define specifically because of the overabundance of definitions. To qualify my use of the concept "identity" and contextualize its significance for adolescence and YA fiction, I refer to Robyn McCallum's work. McCallum prefers to use the word "subjectivity" instead of identity, and defines it as "an individual's sense of a personal identity as a subject-in the sense of being subject to some measure of external coercion-and as an agent-that is, being capable of conscious and deliberate thought and action" (1999, p. 4). At its core, her definition argues for a perspective that strikes a balance between socio-cultural factors and personal agency/the self.

Simply listing intertexts as defining Jacob's identity would disproportionately emphasize socio-cultural elements, disregarding Jacob's agency. Rather, I hope to demonstrate that approaching Jacob's identity as an intertextual construct can instead be a pathway of analysis that maintains this balance; in short, while the intertexts Jacob encounters in Postcards are filtered through the socio-cultural environment, he is also shown to consciously process and evaluate some of these new intertexts. In this light, McCallum talks about how "the degree to which the subject is represented as empowered or disempowered by the social and linguistic structures [i.e. the intertexts] through which it is constituted, [has] implications for the possibilities of agency, resistance and transgression" (1999, p. 104). I will attempt to illustrate how Jacob is mostly empowered through the new intertexts he is offered.

Such a view of identity is especially relevant for the adolescent period. McCallum has argued that "the modern concept of adolescence is [a] recent cultural invention" 
(1999, p. 5), citing YA fiction as being one of the cultural narratives that shapes and forms adolescence as a concept. In that context, one of the most common narratives with regards to what adolescence "is", is that is an intense state of identity change/ development. This narrative became popular in large part through psychological theories of child-development, especially those of Erik Erikson, which have long supported the idea of an adolescent "identity crisis" (Erikson, 1971, pp. 135-136); interestingly, even the earliest nineteenth century considerations of adolescence as a distinct period already acknowledged it as one marked by a changing identity with a high level of susceptibility to outside influences (Demos and Demos, 1969, p. 634; 637).

Regardless of whether one believes adolescence is primarily a cultural construct, or a well-defined developmental period, the belief that adolescence is marked by an intense involvement in identity is often present in both. McCallum herself agrees that this perspective is so prevalent that it is also deeply reflected in YA literature, stating that "[i]t should come as no surprise, then, that ideas about and representations of subjectivity [=identity] pervade and underpin adolescent fiction (McCallum, 1999, p. 3). Others argue that this notion is so widespread that "[i]t has become axiomatic in analysis of YA literature that most of these texts are concerned with both the experience of adolescence and with a young person's formation of identity" (Silver, 2010, p. 123). This may be one explanation for the prevalence of controversial topics in YA fiction and why the committees that dispense awards for YA fiction have been accused of showing bias in favour of books that touch upon controversial topics (Greenway, 2006, p. 99). If it is accepted that "the acquisition of a sense of identity [is] essential for making adulthood decisions" (Maier, 1969, p. 57), then adolescence is the vital period to develop one's own views on topics such as sexuality, faith and gender, which then is reflected in YA fiction. Similarly, Karen Coats writes that "YA fiction is organized around the same sorts of tensions that preoccupy the physical bodies and emotional lives of its intended audience" (2011, p. 316). She also affirms YA fiction's importance for adolescent identity, writing that "young adult literature exerts a powerful influence over its readers at a particularly malleable time in their identity formation" (2011, p. 315). Therefore, the prevalence of controversial topics in YA fiction reflects adolescents' developmental need to consider how these topics, which are also texts, fit into the larger tapestry of their intertextual identity. Such a perspective recognizes both adolescent agency in considering their identity, and the reality that the intertexts are offered through a sociocultural filter. It is the interplay between all factors mentioned above that create such fertile ground for an intertextual analysis of a fictional character's identity in YA fiction.

\section{Analysis of Aidan Chambers' Postcards from No Man's Land}

If the adolescent period is preoccupied with identity formation, and identity is an intertextual construct, then analysing how the intertextual environment in Postcards affects the protagonist's adolescent identity means discussing how his identity changes through his experiences with various intertexts. In the following paragraph 
from Postcards' final chapters, Jacob reflects on how the novel's events have impacted him:

It was as if his self were a sort of three-dimensional jigsaw made of pliable bits which could be combined in to a number of different beings, different Jacobs, rather than just one. Now the bits were moving around, shaping a self who startled him. (1999, p. 301)

Not only is Jacob's identity acknowledged as constructed out of various "bits" (which can be read as intertexts), their "pliability" illustrates how an individual's intertextual network, expressed as identity, can also change even without adding new intertexts, by reconfiguring existing intertextual relations into a new "self". This confirms not only Jacob's struggle with his own identity, but presents it as a "pliable" intertextual network in which the novel's events have triggered a change.

Postcards is especially suitable for this type of analysis for multiple reasons. First, Chambers' YA novels are known for being "investigation[s] of the consciousness of a young person" (Greenway, 2006, p. 87). Second, among those investigations of consciousness, Postcards not only transports its protagonist into a thoroughly different intertextual environment, from England to Amsterdam, it also explicitly emphasizes the impact this shift has on the main character's identity, using language that, as I have argued, evokes intertextual principles. Third, Postcards' plot deals with the types of controversial topics that are vital to adolescent identity creation.

The novel follows the story of Jacob Todd, a 17-year-old English teenager who travels to Amsterdam. Jacob's grandfather had been a soldier during WWII, and after being wounded was hidden and cared for by the Dutch Wesseling family. Whilst in Amsterdam, Jacob stays with Daan, the grandson of Geertrui Wesseling, who introduces him to the art of Rembrandt, polygamy and queer sexualities. Eventually, Jacob learns that his grandfather and Geertrui had an affair from which Daan's mother was born. This revelation causes Jacob to question his identity even more in the midst of an experience which had already presented him with many new intertexts. Amsterdam plays an important role in that process, which I will be discussing first.

Following Still and Worton's assessment that "we [...] construct our 'lives' in relation to texts" (1990, p.19), Jacob's displacement from England to Amsterdam significantly increases the available intertexts through which he can construct his identity. This increase is so great because Amsterdam functions as a socio-cultural "gateway". The city is known to be generally tolerant towards drugs, queer sexualities and other "alternative" lifestyles. This creates an eclectic intertextual web which stimulates experimentation, therefore functioning as a catalyst that pushes Jacob out of his comfort zone.

Amsterdam is the perfect incubator for Jacob's struggles with his identity because they both embody a clash between old and new. While walking through the city, Jacob notices "the modern ads and familiar international icons, Burger King, Pepsi, Heineken, that adorned/polluted the old high-peaked Dutch facades" (1999, p. 10). Both adorned and polluted, the city itself appears unsure where in its oldworld network to incorporate these new capitalist/foreign intertexts. In comparison, while Jacob is "only" 17, he has lived with his grandmother for years and has a 
stronger connection with her than with his siblings, parents and peers (1999, pp. 34, 140-148). Though this does not automatically mean Jacob has an "old" frame of mind, he admits he and his grandmother are much alike (1999, pp. 140-148), and when he asks his Dutch love-interest Hille, "Am I old-fashioned? Maybe I am", she replies, "Yes, I think that's true. I agree[...]. Not out of date or anything.[...] Just old-fashioned" (1999, pp. 223-224).

Old-fashioned Jacob's arrival in Amsterdam then starts a process where he, like the city, struggles with incorporating new influences into his "old" network. This theme of "new" occupying "old" is so important for the book that it is introduced in the very first sentence, "Amsterdam is an old city occupied by the young" (Chambers, 1999, p. 5). Accordingly, there is a strong parallel between the changes that Jacob and Amsterdam are both in the midst of. By being the environment through which Jacob is introduced to an extensive spectrum of intertexts, ranging from polygamy (Chambers, 1999, p. 299), homosexuality (Chambers, 1999, p. 11), and euthanasia (Chambers, 1999, p. 104), to the works of Rembrandt (Chambers, 1999, p. 90) and Bram Vermeulen (Chambers, 1999, p. 98), Amsterdam becomes the crucible of Jacob's identity. His arrival there truly is "his first day in the city and the last day of his previous life" (Chambers, 1999, p. 316).

Bloom argues that there are a handful of authors who serve as "fathers" for the authors that came after them. He explains this through what he calls facticity, "the unavoidability of certain writers" (Allen, 2011, p. 135). These dynamics of influence Bloom coined can, with some recalibration, also illustrate intertextual relations on the level of the individual text, in the Kristevan sense. If, in a Bloomian paradigm, modern authors suffer anxiety due to the influence of an unavoidable "father", then the same can be said of Jacob's relationship with his grandfather, who even carries the same name. Though Jacob's identity may be an incredibly intricate fabric/text that consists out of uncountable threads, the one thread that runs through the core of the entire tapestry, which he cannot seem to escape from, is his grandfather. While modern authors are influenced by literary fathers whose works they have never read, Jacob's entire life is determined by a grandfather he never met. Their shared name is the most apt example, with him being named Jacob in honour of his grandfather (1999, p. 142-143). Jacob is keenly aware of this connection, exclaiming that" [...] for God's sake! I'm supposed to be him reincarnate" (1999, p. 288).

Young Jacob cannot seem to escape from his grandfather's influence, as virtually every major narrative event he experiences, connects to Old Jacob. The very reason he arrives in Amsterdam is because of the anniversary of his grandfather's death. People he initially thought were just friends, turn out to be children and grandchildren born of his grandfather's affair. If an author's facticity is his unavoidability, then Old Jacob's facticity as a text means that Young Jacob cannot help but quote him in the Kristevan sense. Jacob's "significance" can only be fully understood via knowledge of Old Jacob as an intertext. And as Bloom suggests, Jacob's inability to avoid "quoting" his grandfather indeed triggers anxiety, such as when Jacob discusses hiding his grandfather's affair from his grandmother: "Almost as if I were my grandfather and she were my wife. Stupid, eh? The anxiety made him restless" (1999, p. 328). 
Importantly, the anxiety Jacob feels here is not born from any dislike for his grandfather; he even wishes "he had known the man whose name he bore and who he was supposed to resemble in so many ways" (1999, p. 183). Instead, Jacob's anxiety emerges from a fear of not being "original". To adapt a paragraph by Bloom, because Jacob is:

[t]hreatened by the prospect of imaginative death, of being entirely possessed by a pre-cursor, [he] suffer[s] a [...] form of crisis. A strong poet seeks not simply to vanquish the rival but to assert the integrity of his or her own writing self. (Bloom, 2011, p. 8)

Thus, the inevitability of his grandfather's text does not prohibit Jacob from asserting his own integrity by finding and connecting to new intertexts. This is how, to paraphrase McCallum, he is empowered through the intertexts he encounters in Amsterdam (1999, p.104).

Jacob's adventure in Amsterdam expands the intertextual network which constitutes his identity, but if "everything is a text" (Irwin, 2004, p. 229), then there is no limit to what can be analysed as an intertext. However, as Riffaterre wrote, "we must distinguish between the actual knowledge of the form and content of that intertext, and a mere awareness that such an intertext exists and can eventually be found somewhere" (1990, p. 56). So, while technically everything Jacob encounters is an intertext, some can be identified or discussed while most cannot. One example is the painting Titus as a Monk by Rembrandt van Rijn, the importance of which will be demonstrated later.

Because Jacob is "constituted by the texts of [his] culture" (Clayton and Rothstein, 1991, p. 22), some of his internalized intertexts clash with Daan's, who is constituted by different cultural texts. This becomes clear in the midst of a discussion on the topic of marriage and gender. At one point, Daan argues that: "All the stuff about gender. Male, female, queer, bi, feminist, new man, whatever-it's meaningless. As out of date as marriage for ever.[...] We're beyond that now"' (1999, p. 299). In reply, Jacob argues that: "'You are, maybe,' [...]. 'Not all of us, though. Not most of us probably. Not where I come from anyway"” (1999, p. 299).

This passage demonstrates the differences in the intertexts "marriage" and "gender" within Daan and Jacob's contrasting intertextual webs. It also shows how Jacob struggles with his identity in this foreign environment. He shifts from an absolute statement about him as part of a group "us", to highlighting himself as an individual not necessarily in accord with a group, by stating that things are different where he comes from.

On a more concrete level, Jacob's identity is marked by a strong literary background, and he regularly comments on events through literary allusions. For example, he often references Shakespeare $(1999$, p. 33; 101; 157; 171; 259; 292), doing so for the first time after he is mugged: " $[\mathrm{H}]$ is mood [was] encouraged by the rain. Hamlet was dead right. How weary, stale, flat and unprofitable were all the uses of this world" (1999, p. 33).

Jacob's extensive quoting of Shakespeare is an early indication of the singular focus of his literary background, which is a result of his grandmother's influence: 
'You're a reader, then?' Alma said.

'A lot. From living with my grandmother.' (1999, p. 47)

As far as actual literary texts exist as nodes within the intertextual network with which Jacob enters Amsterdam, they are predominantly English texts. When he examines a bookcase, the English works stand out to him as "friends among strangers" (1999, p. 68). The range of his reading is in fact demonstrated through the titular "Postcards". These refer to the postcards his grandmother regularly sends him that include "a quotation from something she's reading, or she's heard on television, or [...] a clipping out of a paper or a magazine" (1999, p. 330). Thus, the quotes represent the types of works his grandmother favours, and by extension which Jacob has been motivated to adopt into his identity during his stay with her. These are almost all works by pre-twentieth century English authors, such as John Webster, William Blake, Lewis Carroll and Lord Byron. At first glance, Anne Frank's diary seems the major exception, as a Dutch work, yet the only version Jacob is familiar with is the common English translation. Furthermore, Jacob's discovery that the Dutch version is a broader, more complete edition is an important narrative event. This news triggers "[a]n angry anxiety [...], as if he had been denied some life-sustaining information" (1999, p. 199).

Greenway argues that when a thief steals Jacob's belongings at the beginning of the story, he is "symbolically [...] stripped of his past identity." (2006, p. 96). I agree that this event is important for Jacob's identity, but disagree with Greenway's suggestion that his identity is "stripped" from him. The mugging should also not be considered on its own. Instead, it is only one encounter in a sequence of events which together wrench open Jacob's identity and allow him to be open to Amsterdam's intertexts. The first of these events is Jacob's visit to the Anne Frank house.

Upon arriving in Amsterdam, Jacob immediately heads for the Anne Frank house because "it was the only place [he] knew about and wanted to go to" (1999, p. 319). Thus, his desire to see Anne Frank's house is rooted in his obsession with her diary, which, like his grandfather, is a core thread of his intertextual tapestry. When Jacob enters the Anne Frank house, he immediately balks at the large number of other tourists. He has such an intimate relationship with the Diary that he is unable to "share" Anne and he almost lashes out, "I wanted to shout at them, 'Go away! Leave her alone! You've no right here! Get out!'” (1999, p. 322). At core, what causes this rage is Jacob's refusal to reconsider an intertext central to his identity. Yet, he is left no choice and Jacob's intimate relationship with Anne Frank is his first intertext transformed by Amsterdam. This first change is also the one that must overcome the most resistance. As Vanessa Joosen writes, "Jacob's visit to the museum is presented as a necessary step in coming of age, ripping him out of the illusion that he was Anne Frank's sole addressee" (2018, p. 89). Joosen's use of "ripping" is indicative of Jacob's intense response, as he runs out into the street dazed, confused and "too jangled by what he had just seen to notice where he was and too preoccupied to wonder where he was going" $(1999$, p. 5). This is the first major step in the "unravelling" and "re-weaving" of Jacob's identity.

After leaving the Anne Frank house, Jacob flees to the Leidseplein. There he meets Ton, an Amsterdam native who denounces the Leidseplein as a tourist trap 
(1999, p. 8). However, the source for Ton's dislike is exactly what attracts Jacob. The Leidseplein is an intertextually safe zone. It caters to tourists and is therefore not meant to disrupt or disturb. Once there, Jacob tries to recover from the events at Anne Frank's house by retreating into comfortable intertextual boundaries within which he is protected from further change. This attempt fails because of Ton. While Jacob desires stability and safety, Ton offers the opposite. When they order drinks, Jacob's reluctance to consider any new intertexts manifests even in his drink of choice, Coca Cola. However, Ton pressures him into drinking a "good Dutch beer" $(1999$, p. 7). Following this minor imposition of a Dutch intertext, Ton lands his biggest blow on Jacob's identity. While Jacob thought Ton to be female, he discovers Ton is actually a feminine gay teenage boy when Ton presses Jacob's hand into his crotch. The shock of this realisation again hits Jacob hard, leaving him in a "daze" (1999, p. 11). This is immediately followed by a thief knocking Jacob down and stealing his belongings, leaving him no room to recover from the previous blow. While the theft is partly illustrative of Jacob losing his grip on his old identity, the ensuing chase also draws him deeper into the city through small alleyways and roads not visited by tourists, leading him away from the last area where his old intertextual network was protected (1999, p. 12).

After losing the thief, Jacob eventually arrives at Daan's apartment. The first thing Daan exclaims upon seeing Jacob is: 'Mijn God! Titus!' (1999, p. 66). The meaning is completely lost on Jacob until Daan shows him the painting Titus as a Monk by Rembrandt, and it is revealed that Jacob strongly resembles the subject of the painting, Rembrandt's son Titus. Jacob's reaction to the painting is intense, "[n]o picture he had ever seen had so absorbed and fixated him" (1999, p. 92). Yet, this is contrasted with his assessment that "the picture was not impressive. Had he been wandering on his own through the gallery he might easily have passed by without noticing it, just as other people were now" (1999, pp. 91-92). Though this contrast might at first seem strange, it in fact hints at the intertextual connotations Jacob subconsciously reads in the painting. The resulting scene consists of two layers. Superficially, there is the physical appearance of the painting itself, which yet again reinforces Old Jacob's facticity for Young Jacob, as seen in the following paragraph: "And the feature which took most of Jacob's attention because he hated it so much, the long thick nose with its blunt and bulbous end.[...] His grandfather's nose" (1999, p. 90).

While the painting's "blunt" nose may be apparent for every visitor, only Jacob arrives with the intertextual network in which that nose reminds him of his unavoidable grandfather. Yet, Jacob's immediate obsession with the painting cannot be explained purely by this grandpaternal connection found in the painting's superficial appearance. This, as I have argued, is a source of anxiety, not obsession. Jacob's intense reaction comes from his own deeper analysis. What attracts him to the painting, and what becomes important for his identity, is the dynamic between the painter (Rembrandt, the father), and the painted (Titus, the son), an intertext on the nature of love. In other words, Jacob is not deeply affected by the superficial text, but by an important part of the intertextual network beneath that text. Daan puts Jacob's passion into words as follows: 
$[\mathrm{R}]$ eal love is observing another person and being observed by another person with complete attention. [...] [Y]ou only have to look at the pictures Rembrandt painted of Titus [...] to see that they loved each other. Because that is what you're seeing. Complete attention, one of the other. (1999, p. 96)

To which Jacob replies, "all art is love, because all art is about looking closely, isn't it. Looking closely at what's being painted" (1999, p. 96). This moment offers Jacob a vital intertext, the adoption of which guides the rest of his stay in Amsterdam. Greenway phrases it as follows, "If the history of art is the history of love, [...] then love can also be for a thing or a place, for as Jacob observes Holland more and more closely, he comes to like it more and more, then love it" (2006, p. 95). Jacob's opening up to Amsterdam and its intertextual space therefore relies on his internalization of this abstract intertext on the nature of art/ love found in Rembrandt's painting. In this way, the encounter with the painting is the final key moment of transition for Jacob, where he at last opens himself to Amsterdam's influence. This is the culmination of the process that had begun with his visit to the Anne Frank house. Chambers summarizes the entire experience as follows: "this foreign country had begun to strip away from him, like peeling off a protective skin, the few certainties he thought he knew about himself, leaving him disorientated and displaced" (1999, p. 121).

After losing this "protective skin", Jacob is much more welcoming to the new intertexts Amsterdam offers. This change is immediately visible. As Daan and Jacob are leaving the Rijksmuseum, Daan starts singing a Dutch song, "Mijn hele leven zocht ik jou, om—eindelijk gevonden—te weten wat eenzaam is" (1999, p. 98). To which Jacob, not knowing Dutch, responds, “And what's that all about?" (1999, p. 98), finally showing interest in expanding his limited intertextual network, and demonstrating that Jacob is growing in what Riffaterre calls "linguistic competence""the reader's familiarity with the descriptive systems, with themes, with his society's mythologies, and above all with other texts" (Riffaterre, 1978, p. 5).

While Jacob's sudden enthusiasm for Daan's song is telling of the change he has already undergone, there is more to identity than the traditionally "cultural" texts such as literature, language and art. As the narrative progresses, intertexts of sexuality and gender also suggest new queer possibilities. This contrasts with Jacob's native textual environment that has traditional views on sexuality, gender identity, and marriage (1999, p. 299). Jacob encounters many of these intertexts through characters who strongly exhibit them, such as Ton, who happens to be a friend of Daan's. Though there initially is some internal turmoil on Jacob's part when he discovers Ton is a boy, they are attracted and even kiss by the end of the novel (1999, p. 309). Amsterdam presents this intertext of homosexual attraction or love to Jacob on his first day there. In addition, Ton's gender and sexual identity is an intertextual network in its own right. Physically, he appears very feminine, as Jacob's initial attraction to him was based purely in heterosexual desire, which relied on Jacob's internalized intertext of "female appearance". Yet, when Ton's gender is revealed, Jacob remains attracted to him, which illustrates the interconnectedness of intertexts. Ton's appearance doesn't change; rather the intertext "female appearance" is 
now interwoven with intertexts of sexuality and gender identity. Ultimately, Ton's importance for Jacob's identity is based in universal, Dutch and English intertexts, which are all woven together into the text: "Ton".

While Ton's own intertextual identity is also complex, the key intertext personified by Ton for Jacob is the acceptance of homosexual desire. Yet, this is not the only new intertext that is personified through a supporting character. Daan represents a sexually open lifestyle, living in a polygamous relationship with Ton and a girl named Simone. Where Ton identifies as gay (1999, p. 129), Daan, as I mentioned before, claims to completely transcend gender identity and sexual orientation, insisting that "[a]ll the stuff about gender. Male, female, queer, bi, feminist, new man, whatever-it's meaningless" (1999, p. 299).

While Jacob is flirting with Ton, he encounters Hille, a Dutch girl or to whom he is also attracted. He promises Ton that they will meet again in the future, which hints at a non-heterosexual romance, yet Postcards ends with Jacob sleeping with Hille. In these instances, Jacob is experimenting with introducing new, and transforming old intertexts related to sexuality in his own network, from his sexuality itself to the possibility of multiple sexual partners in a polygamous relationship, mirroring Daan's. These are not decisive choices, as much as they are exemplary of the adolescent integrating and experimenting with various strands of identity. Before Amsterdam, Jacob was in a sense intertextually starved, as his grandmother Sarah, who raised him since early adolescence, only offered a limited set of intertexts. In contrast, Amsterdam surrounds him with multiple characters who present and arrange abstract texts in new ways that are useful for the development of his identity. This development is further nurtured by the city's social text which is more open to "alternative" intertexts of gender, sexuality and more, in contrast to the English social text which Jacob is accustomed to. The characters surrounding Jacob often foreground or background intertexts in new ways, or connect intertexts that Jacob had previously considered wholly discordant, such as feminine appearance and male gender in Ton's text.

There are many more texts Jacob is confronted with. He learns that his grandfather, who had always been presented as a paragon of human perfection, was an adulterer. Further, he engages with Hille in a discussion on heroism, in response to Hille's argument that the soldiers who died in Arnhem during the war were not especially heroic (1999, p. 198). Daan and his mother Tessel disagree on the nature of family. Emphasizing genetics, Daan starts calling Jacob "little brother" (1999, p. 298) after revealing they are related, while Tessel argues that "She's a Wesseling, not a Todd [...]. She knew nothing of [Old] Jacob" (1999, p. 291). On the topic of euthanasia, Geertrui, Hille and Daan all argue for its merits, while Tessel is staunchly opposed. Jacob is initially filled with rage towards the thief, only reconsidering his anger when someone asks, "the boy who stole your things, what about him? What kind of life does he live? And who looks after him?” (1999, pp. 44-45).

In my analysis, I have avoided suggesting that Jacob passively absorbs every intertext he encounters. In doing so, I wanted to keep McCallum's balance between the socio-cultural element, and personal agency. Ultimately, it is possible to identify many elements in the narrative as intertexts, but these are not just randomly added to Jacob's own textual network. In McCallum's own analysis of a literary character, 
she writes that "[character] is actively appropriating these texts and discourses as an interpretative schema through which she articulates her sense of herself in relation to this world" (1999, p. 147). Much in the same way, Jacob's active appropriation of some of these intertexts is apparent by the end of the novel. Prior to the novel's events, Jacob had a vague internal image of the person he would like to be, yet struggled with bringing that person to the foreground, thinking that "[h]e had caught glimpses of him more and more often since he was about fifteen" (1999, p. 301). By applying the prior McCallum quote, I propose that Jacob was fundamentally lacking much of the "interpretative schema through which [he] articulates [his] sense of [himself] in relation to this world" (1999, p. 147). This interpretative schema consists of intertexts, and is expanded tremendously through his stay in Amsterdam. The socio-cultural environment may provide these intertexts, yet it is ultimately Jacob who articulates his sense of self through this lens. Consider for example how Jacob goes from dazed shock and confusion over encountering Ton (1999, p. 11), to his perspective on Daan and Ton's relationship by the end of the novel: " 'You should come and join us,' Ton said, laughing. 'Maybe I will,' Jacob said, and felt himself blushing because his tone gave away that he wished it" (1999, p. 301). Further, Jacob decides to learn Dutch after being exposed to the language (1999, p. 332) and after learning of his grandfather's affair with Geertrui, positions himself as a member of his newfound Dutch family (1999, p. 314). These are only some instances where Jacob could have just as easily refused to participate or clung to his old self, yet is not to say Jacob is presented as having completed whatever identity-shift the narrative triggers. After his extensive discussion with Ton and Daan about gender, sexuality, polygamy, death, love, marriage etc.., and his experiences in learning of his grandfather's affair with Geertrui Wesseling, the novel states:

He needed time on his own to work it out. Whatever it was, was mixed up with what he had learned from Geertrui's story, and what he had felt, when he left her that day. And there was Ton and there was Hille. He just had not had enough time to take everything in. (1999, pp. 301-302)

His adoption of these intertexts is not automatic, nor is it passive. In that way, this process mirrors McCallum's perception of identity as being constituted both by internal and external factors. Yes, all these intertexts are offered to Jacob through the socio-cultural environment, but the act of processing and positioning at least some of this new material in his intertextual web requires his "conscious and deliberate thought" (McCallum, 1999, p. 4). Through his experiences with all the characters mentioned on the prior pages, who all have their own beliefs to share, Jacob is engulfed in textual constructions containing abstract intertexts such as sexuality, gender, physical appearance, literature, religious belief, the nature of love itself, war, crime, free will, and more. Considering this, it is perhaps no surprise that towards the end of the novel, his "bits were moving around, shaping a self who startled him" (1999, p. 301). 


\section{Conclusion}

Returning to Kristeva's original interpretation of intertextuality makes it possible to extend an intertextual analysis to adolescent identity itself, which is then seen as a text woven out of intertexts of many kinds. However, such a process of identity development should not be reduced to an image of the self as a purely sociocultural product, and YA characters are also rarely presented as passive sponges of socio-cultural information, often even rebelling against their native socio-cultural environment. Accordingly, in Postcards, Jacob's appropriation of new intertexts into his own intertextual network, empowers him to re-articulate his own sense of self. This process has him engage with difficult topics ranging from euthanasia to sexuality, and while the novel might not present the experience as final, it does suggest it is conducive to a more complete identity for Jacob. Though narratives of identity development are very common in YA fiction, Chambers thematizes this explicitly, keeping the reader up to date on Jacob's identity development through metaphors such as the "three-dimensional jigsaw made of pliable bits" (1999, p. 301).

Regardless of whether YA fiction's emphasis on identity development accurately reflects real adolescent experience, the sheer prevalence of this theme has motivated literary critics to develop theoretical frameworks in an effort to capture how adolescent identity is represented in YA fiction. I therefore believe the value of my approach lies in its capacity to describe characters' identity development, especially in YA fiction. The latter's emphasis on identity often leaves us with characters that we argue have "changed" as a result of the story. Reflecting on the intertextual network that manifests through a given character allows us to visualize this change throughout the narrative, in the sense of specific intertexts being reshaped, developed and added to a pre-existing intertextual web.

I hope my article might spur reflection on how intertextuality (in the Kristevan sense) contributes to characterization in other novels - an interesting avenue to explore in educational contexts on multiple levels. For example, one could ask readers to describe a character's intertextual network at the beginning and end of the book, and use this to start and support a discussion about character growth and the novel's main themes. It would perhaps then be just as interesting to see in which novels readers argue the approach does in fact not work. McCallum identified two extremes of how identity is perceived. On the one hand there are: "essentialist conceptions of the human subject, which ground subjectivity in either consciousness, agency or essential selfhood-as humanism tends to do", while on the other hand there are "mechanistic social theories of subjectivity, which conceive of the subject as "determined by the social object" - as structuralism and poststructuralism have tended to do" (6). Both are problematic for identity analysis in the sense that they conceive of (YA) identity as being completely internal, or completely external. The interaction of an intertextual approach with these (and other) conceptualizations of identity may offer interesting perspectives on how different authors apply characterization, and character growth or agency in their works.

On that note, I believe my intertextual analysis of (adolescent) identity can readily be expanded to Chambers' other novels. The Toll Bridge (1995) also deals with an 
adolescent protagonist struggling with his identity, and while it lacks Postcards' complete sense of displacement, its protagonist is similarly isolated from his usual intertextual network. Further, the approach can also be applied to other YA authors. An intertextual analysis of Mary E. Pearson's The Adoration of Jenna Fox (2008) could discuss how the adolescent protagonist, suffering from memory loss, constructs an intertextual identity out of nothing and evaluates which intertexts to accept or reject. Regardless of the specific novel, the questions remain the same: what intertexts can be identified? How do the characters engage with these intertexts?

To conclude, identity development is a complex process that relies on a multitude of factors. An intertextual analysis can show how in fiction this progress is supported by a narrative intertextual environment that provides the raw intertexts with which to enact change for YA readers, who are constructing their lives in relation to all of their own intertextual experiences.

Acknowledgements The author wrote this article as part of the research project "Constructing Age for Young Readers." This project has received funding from the European Research Council (ERC) under the European Union's Horizon 2020 research and innovation programme (Grant Agreement No. 804920).

Open Access This article is licensed under a Creative Commons Attribution 4.0 International License, which permits use, sharing, adaptation, distribution and reproduction in any medium or format, as long as you give appropriate credit to the original author(s) and the source, provide a link to the Creative Commons licence, and indicate if changes were made. The images or other third party material in this article are included in the article's Creative Commons licence, unless indicated otherwise in a credit line to the material. If material is not included in the article's Creative Commons licence and your intended use is not permitted by statutory regulation or exceeds the permitted use, you will need to obtain permission directly from the copyright holder. To view a copy of this licence, visit http://creativecommons.org/licen ses/by/4.0/.

\section{References}

Allen, Graham. (2011). Intertextuality. 2nd edn. London: Routledge.

Bloom, Harold. (1975). Introduction: a meditation upon misreading. In A map of misreading, (pp. 3-6). Oxford: Oxford University Press.

Bloom, Harold. (2011). The Anatomy of Influence. London: Yale University Press.

Chambers, Aidan. (1999). Postcards from No Man's Land. London: The Bodley Head.

Clayton, Jay and Eric Rothstein. (1991). Figures in the Corpus: Theories of Influence and Intertextuality. In Jay Clayton and Eric Rothstein (ed.) Influence and Intertextuality in Literary History, (pp. 3-36) Madison: The University of Wisconsin Press.

Coats, Karen. (2011). Young Adult Literature: Growing Up, In Theory. In Shelby A. Wolf et al (ed.) Handbook of Research on Children's and Young Adult Literature, (pp. 315-329). London: Routledge.

Demos, John and Virginia Demos. (1969). Adolescence in Historical Perspective. Journal of Marriage and Family, 31(4), 632-638.

Erikson, Erik H. (1971). Identiteit, jeugd en crisis. Amsterdam: Het Spectrum.

Greenway, Betty. (2006). Aidan Chambers: Master Literary Choreographer, Lanham: Scarecrow Press.

Irwin, William. (2004). Against Intertextuality. Philosophy and Literature, 28(2), 227-242.

Joosen, Vanessa. (2018). Renegotiating cultural heritage and personal belonging: the Anne Frank Museum in Aidan Chambers's Postcards from No Man's Land and John Green's The Fault in Our Stars. Journal of the history of childhood and youth, 11(1), 87-94.

Kristeva, Julia. (1986). The Kristeva Reader. Ed. Toril Moi. New York: Columbia University Press.

Maier, Henry W. (1969). Three Theories of Child Development, London: Harper \& Row.

McCallum, Robyn. (1999). Ideologies of Identity in Adolescent Fiction: The Dialogic Construction of Subjectivity. New York \& London: Garland. 
Mertz, Maia P. (1978). The New Realism: Traditional Cultural Values in Recent Young-Adult Fiction. The Phi Delta Kappan, 60(2), 101-105.

Pfister, Manfred. (1991). How Postmodern is Intertextuality? In Heinrich F. Plett (Ed.), Intertextuality (pp. 207-224). Berlin: Walter de Gruyter.

Polaski, Donald C. (2001). Authorizing an End: The Isaiah Apocalypse and Intertextuality, Leiden:Brill.

Riffaterre, Michael. (1978). Semiotics of Poetry. Bloomington: Indiana University Press.

Riffaterre, Michael. (1990). Compulsory reader response: the intertextual drive. In Michael Worton and Judith Still (Ed.), Intertextuality: Theories and practices (pp. 56-78). Manchester: Manchester University Press.

Silver, Anna. (2010). 'Twilight' Is Not Good for Maidens: Gender, Sexuality, And the Family In Stephenie Meyer's 'Twilight' Series. Studies in the Novel, 42 (1/2), 121-138.

Smith, Russell. (2019). Young-adult fiction continues to invite moral drama, on and off the page. Retrieved May 5, 2019 from https://www.theglobeandmail.com/arts/books/article-young-adult-fiction-continuesto-invite-moral-drama-on-and-off-the/.

Still, Judith, and Micheal Worton. (1990). Introduction. In Michael Worton and Judith Still (Ed.), Intertextuality: Theories and practices (pp. 1-45). Manchester: Manchester University Press.

Publisher's Note Springer Nature remains neutral with regard to jurisdictional claims in published maps and institutional affiliations. 